\title{
First records of the genus Pseudoniphargus (Amphipoda) from Gran Canaria, with description of a new species
}

Stygofauna of the Canary Islands, 17

\author{
Elias Sánchez \\ Departamento de Biología Animal, Universidad de La Laguna, Tenerife, Canary Islands
}

Keywords: Amphipoda, Pseudoniphargus, ground waters, Gran Canaria, Canary Islands

\begin{abstract}
A new species of Pseudoniphargus has been discovered in Gran Canaria in a spring at an altitude of $710 \mathrm{~m}$ a.s.l.; it has an elongate peduncle of the male uropod 3. Moreover, $P$. fontinalis was found in the same island; this is the first record outside Tenerife from where it was described. The biogeographical implications of these records are studied.
\end{abstract}

\section{Resumen}

Una nueva especie del género Pseudoniphargus es descubierta de Gran Canaria (Archipíelago canario), de una fuente a $710 \mathrm{~m}$ sobre el nivel del mar; presenta alargamiento del pedúnculo del uropodo 3 en el macho. $P$. fontinalis es descubierta sobre Gran Canaria, es la primera vez que se cita dicha especie fuera de Tenerife, de donde es descrita. Se realiza un estudio de las implicaciones biogeográficas.

\section{Introduction}

Up to the moment nothing was known about the stygofauna of Gran Canaria, except for a single juvenile of Pseudoniphargus (cf. Stock, 1988: 47), which we re-examined in the present study.

A new species of this genus was found in a spring at $710 \mathrm{~m}$ above sea-level. The peduncle of uropod 3 in the male is elongate, making this the first species with this character discovered in the Canary Islands. Furthermore the variability of $\boldsymbol{P}$. fontinalis, rediscovered in Gran Canaria (originally described from Tenerife) is studied; this is the first time that a species of Pseudoniphargus from Tenerife was discovered on another island of the Canary archipelago.

Since the original description (Chevreux, 1901) and the first revision (Karaman, 1978), the genus contains an increasing number of species (Boutin \& Coineau, 1988; Notenboom, 1986, 1987a, 1987b; Pretus, 1989; Sánchez, in press; Stock, 1980, 1988; Stock et al., 1986). A phylogenetic analysis and biogeographical study was made by Notenboom (1988), excluding however the Canarian-African taxa.

The genus is known from the western Canarias (Tenerife, La Palma, Gomera and Hierro), and now from Gran Canaria. From Lanzarote and Fuerteventura no species of this genus are known at the moment. Since both islands have thoroughly been sampled, their unexplained absence appears to be realistic.

\section{Biogeographical remarks}

The volcanic history of Gran Canaria is characterized by the existence of three volcanic cycles; first (14-9 My BP, Miocene), second (4.5-3.4 My BP, lower Pliocene) and third (2.8 My to 3500 years old), each cycle being separated by erosive intervals (Araña \& Carracedo, 1978).

The presence of $P$. pedunculatus n. sp., at considerable altitude, can be explained by these volcanic cycles, inactivity periods and sea level changes. 


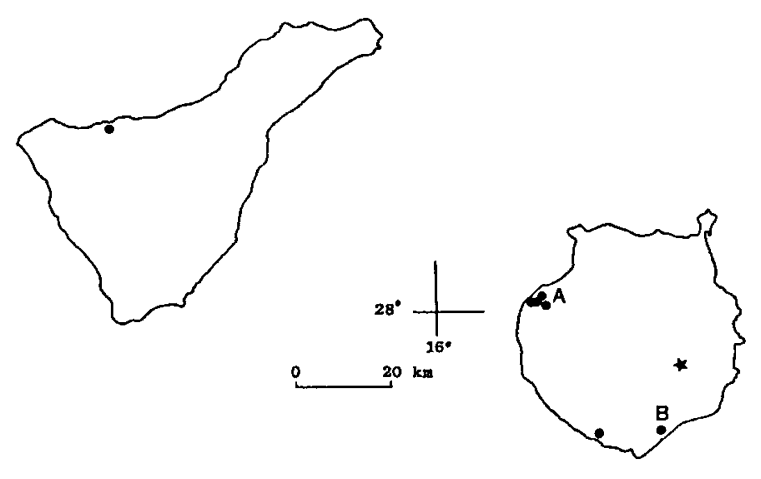

Fig. 1. Distribution of $P$. fontinalis $(\bullet)$ and $P$. pedunculatus $\left({ }^{*}\right)$ in Tenerife (left) and Gran Canaria (right). A: Barranco de la Aldea, B: Maspalomas.

The highest level of the sea was estimated at $400 \mathrm{~m}$ above present level (Araña \& Carracedo, 1978).

After the first volcanic cycle, an invasion was possible of the marine ancestor of $P$. pedunculatus n. sp. (which belongs to the branchiatus group), later, during the erosive interval with marine regression, this ancestral species got "stranded": The ancestor may be the same Tethyan taxon (late Oligocene-early Miocene) that later arrived on the Mediterranean coasts when the desiccation of the Mediterranean came to an end in the late Messinian, ca. $6 \mathrm{My}$ ago (in the Betic zone of continental Spain there are the following species of the Pseudoniphargus: $P$. sorbasiensis, $P$. gracilis, $P$. granadensis, $P$. grandis, and $P$. stocki, most of which belong to the branchiatus group; Notenboom, 1988).

It is possible that between the second cycle and the Recent volcanic episode, a second invasion of Pseudoniphargus took place. $P$. fontinalis was found in 3 localities, both in the recent alluvial zone of Gran Canaria (Barranco de la Aldea, San Nicolas de Tolentino and Maspalomas, Playa del Ingles). In Tenerife it was found only in Garachico, where dispersal is not likely because the area has had a recent volcanic episode (Volcano of Montaña Negra, 1706) (fig. 1). This coincidence and the existence of intrusion of marine waters in the Barranco de la Aldea and Maspalomas (Gran Canaria) where $P$. fontinalis was found, induce us to believe that the presence of $\boldsymbol{P}$. fontinalis can be explained by a second, more recent, invasion of the genus in the Canary Islands.

\section{P. fontinalis Stock, 1988}

Material (all from Gran Canaria). -

1 juv. (2.5 mm). Playa del Ingles, spring near the beach (Urbanización California). U.T.M.: 28 R DR 44166970. 7 Feb. 1988; conductivity $6.13 \mathrm{mS} / \mathrm{cm}$; Prof. Dr. J.H. Stock collector.

$1 \sigma^{\circ}(4 \mathrm{~mm}), 1$ ( $1 \mathrm{~mm}$, setose oostegites), 1 \% (4.5 mm) and 5 other specimens. Well in Marciega, La Aldea, San Nicolas de Tolentino. Open well of $39 \mathrm{~m}$, water level at $17 \mathrm{~m}$, with old wind-pump. U.T.M.: 20659701, distance from the sea board $1250 \mathrm{~m} .22$ Oct. 1988 ; temp. $25.3^{\circ} \mathrm{C}$; cond. $4.87 \mathrm{mS} / \mathrm{cm}$; S 2.2 p.p.t.; and 24 Feb. 1989 ; temp. $21^{\circ} \mathrm{C}$; cond. $3.96 \mathrm{mS} / \mathrm{cm}$; S 2.3 p.p.t.

2 specimens (damaged, probably this species). Closed well in Marciega, La Aldea, San Nicolas de Tolentino. Well of $20 \mathrm{~m}$, water level at 10 m. U.T.M.: 20709700. 22 Oct. 1988; temp. $26^{\circ} \mathrm{C}$; Cond. $3.96 \mathrm{mS} / \mathrm{cm}$; $\mathrm{S} 2.8$ p.p.t.

1 ( $3.7 \mathrm{~mm}$, ovigerous with 3 eggs) and 1 other specimen. Well in Marciega, La Aldea, San Nicolas de Tolentino. Open well of $16 \mathrm{~m}$, water level at $10 \mathrm{~m}$, with old wind-pump. U.T.M.: 20259725. 24 Feb. 1989; temp $21^{\circ} \mathrm{C}$; cond. $5.97 \mathrm{mS} / \mathrm{cm}, \mathrm{S} 3.1$ p.p.t.

2 specimens (damaged, probably this species). Cata (well without use) in Marciega, La Aldea, San Nicolas de Tolentino. Depth $18 \mathrm{~m}$, water level at $8 \mathrm{~m}$. U.T.M.: 20459725. 24 Feb. 1989; temp. $22.5^{\circ} \mathrm{C}$; cond. $5.13 \mathrm{mS} / \mathrm{cm}$; S 3.0 p.p.t.

1 ᄋ (4 mm, setose oostegites). Barranco del Lechugal. Well of $54 \mathrm{~m}$, water level at $12 \mathrm{~m}$, with oil-pump in a house. U.T.M.: 28507525. 24 Feb. 1989 ; temp. $23^{\circ} \mathrm{C}$; cond. $2.85 \mathrm{mS} / \mathrm{cm}$, S 2.0 p.p.t.

Accompanying fauna. - Mollusca (Hydrobia spec.), Collembola, Ostracoda, Copepoda, Cladocera and larvae of Diptera.

Additional descriptive notes. -

Mandible palp: 2nd segment with 4-5 setae; 3rd segment with $1 \mathrm{~A}$-seta, 1 to $3 \mathrm{~B}$-setae, $3 \mathrm{E}$-setae and 8 to $10 \mathrm{D}$-setae (juv. $2.5 \mathrm{~mm}$ : 2 nd segment with 2 setae; 3rd segment with 5 D-setae, 2 E-setae, 1 Aseta, 1 B-seta).

Maxilla 1 (fig. 2b). Palp with 6-7 setae (juv. 2.5 $\mathrm{mm}$ with 4). Outer lobe: 7 spines ornamented (from lateral to medial) with $1: 3: 0-1: 2-3: 1-3: 0-2: 2-$

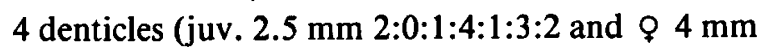
Barranco del Lechugal with 7 multidenticulate spines). Inner lobe: 1-2 distal setae. Maxilla 2: Outer lobe ornamented with 2 groups of the setae; the first consisting of 5 long and 1 short setae, the other of ca. 10 or more distal elements. Inner lobe with 1 group of ca. 10 or more distal elements, very 


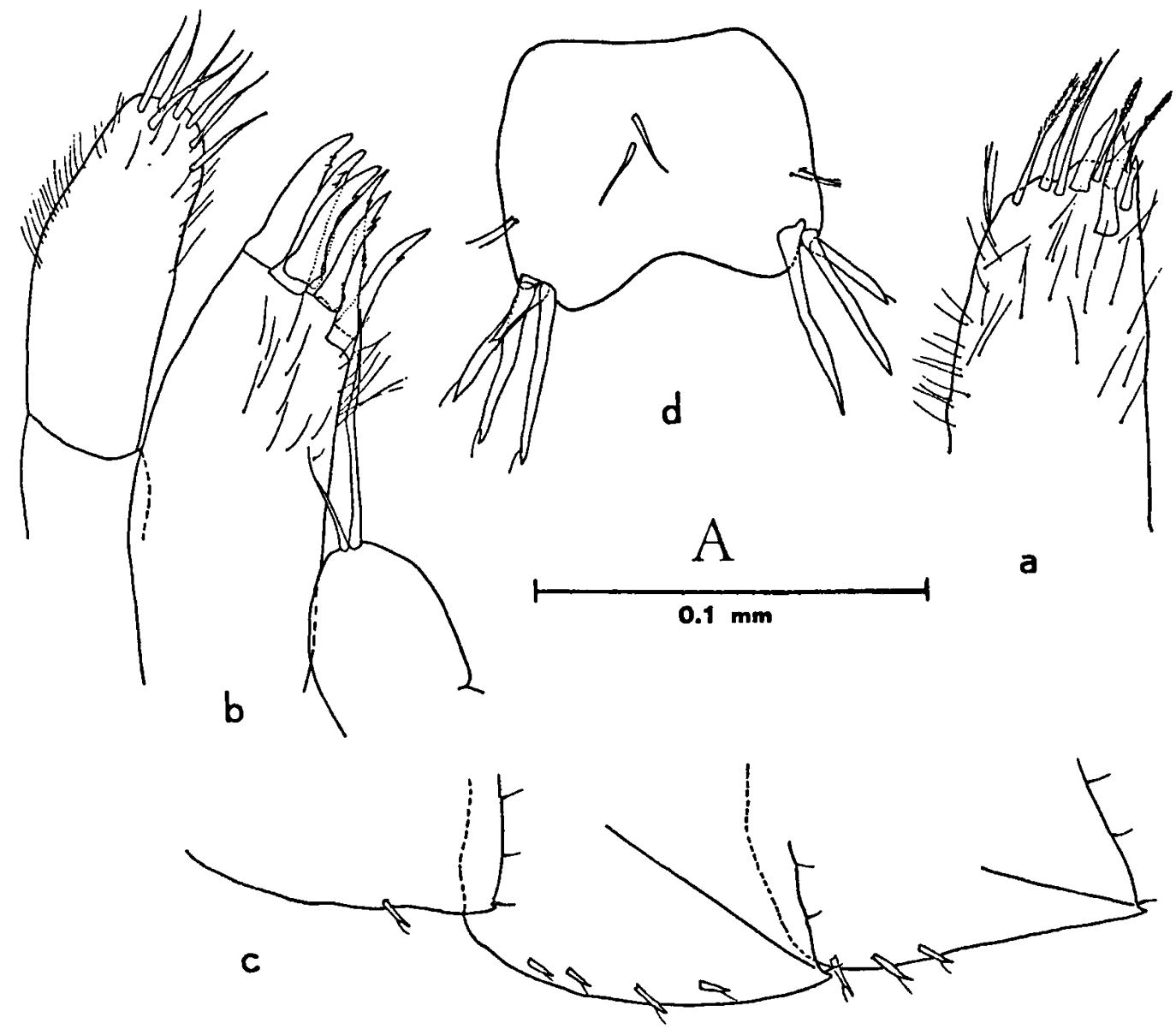

Fig. 2. P. fontinalis Stock, 1988. a: Inner lobe of maxilliped ( $95 \mathrm{~mm}$ ) (scale A); b: maxilla 1 ( 5 mm) (A); c: epimeral plates ( $\sigma$ $4 \mathrm{~mm}$ ) (E); d: telson (\$ $4.5 \mathrm{~mm})(\mathrm{C})$.

densely implanted. Maxilliped: Inner lobe (fig. 2a) with 2 distal spines, 2 subdistal spinules and 4-5 distal setae ( $83.7 \mathrm{~mm}$ ovigerous and juv. $2.5 \mathrm{~mm}$ as in Stock, 1988).

Gnathopods: Mainly variable in chaetotaxis, but also in some other characters. Gn. 1, \& $4.5 \mathrm{~mm}$ (Barranco de la Aldea): posterior margin of carpus with 4 groups of setae and 6 spines on palmar angle; o $4 \mathrm{~mm}$ (Barranco del Lechugal): posterior margin of carpus with 4 groups of setae and posterior margin of propodus with only 1 group of setae; juv. 2.5 $\mathrm{mm}$ : posterior margin of carpus with 2 groups of setae, posterior margin of propodus with only 1 group of setae and 3 spines on palmar angle. Gn. 2, Q $4.5 \mathrm{~mm}$ (Barranco de la Aldea): 5 groups of setae on posterior margin of propodus and 4 spines on palmar angle; $\$ 4 \mathrm{~mm}$ (Barranco del Lechugal): posterior margin of carpus with 3 groups of setae; juv. $2.5 \mathrm{~mm}$ : posterior margin of propodus with 2 groups of setae.

Pereopods: Variation in setation and spinosity is as follows; P3: 3-4 setae on ventral margin of coxal plate. P4: Posterior emargination in large specimens deeper than Stock's description, with 5-6 setae on ventral margin of coxal plate ( 3 in juv. 2.5 $\mathrm{mm}$ ) and fewer (3-7) on posterior margin of basis. P5: Posterior margin of basis with 12-14 setules (6-7 in juv. $2.5 \mathrm{~mm}$ ) and 8 spines on anterior margin (11 in $\$ 4.5 \mathrm{~mm}$ from Barranco de la Aldea and 3 in juv. $2.5 \mathrm{~mm}$ ). P6: Posterior margin of basis with 10-17 setules, and 7-9 spines ( 3 in juv. 2.5 $\mathrm{mm}$ ) on anterior margin. P7: $12-15$ setules on 
posterior margin of basis (7 in juv. $2.5 \mathrm{~mm}$ ), and 5-8 spines on anterior margin.

Epimeral plates (fig. 2c). We found the following variations in the armature of the ventral margin: 1-2 spines on the 1st, 3-4 on the 2 nd, and 3 on the 3rd plate ( $\odot 4 \mathrm{~mm}$ from Barranco del Lechugal and juv. $2.5 \mathrm{~mm}$ with only 1 spine on the ventral margin on all plates).

Uropods. U1: With basofacial spine (except in $\sigma^{\circ}$ $4 \mathrm{~mm}$ from Barranco de la Aldea), 3-4 distal spines $(2+1$ or $2+2), 1-3$ spines on peduncle and $1-2$ spines on endopodite, sometimes with 1 spine on exopodite ( $\$ 4 \mathrm{~mm}$ Barranco del Lechugal) or rami unarmed (juv. $2.5 \mathrm{~mm}$ ). U2: 3 distal spines $(2+1)$, 1-2 dorsal spines and 1 spine on exopodite (juv. 2.5 mm without spine on exopodite). U3: Number of marginal spines $3-5$, remaining characters as in Stock, 1988.

Telson (fig. 2d): Distal cleft deeper; more laterodistal spines (3-5) or only 1 in juv. $2.5 \mathrm{~mm}$.

\section{Remarks}

The main differences between the original drawings and the present material are found in the inner lobe of maxilliped of large specimens (4-5 mm from Barranco de la Aldea), the spinosity of the palmar angle of $\mathrm{Gn} 1$ and $\mathrm{Gn} 2$, and number of groups of setae on the posterior margin of carpus and propodus of Gn 1 and Gn 2. The rest is as in Stock, 1988.

These differences can be attributed to different age stages of specimens from Gran Canaria (2.5-5 $\mathrm{mm}$ ) and the specimens from Tenerife (3.5-4 mm). The age stages show variability in density of the armature of appendages (Notenboom, 1987b).

These characters and the constancy of the following characters: elongation of U3 ( $\odot$ and $\sigma^{\circ}$ ), shape of the basis of P5-P7, general ornamentation of the spines on the outer lobe of Mxl and general shape of the telson, convinced me that the specimens from Gran Canaria belong to $P$. fontinalis Stock, 1988.
Pseudoniphargus pedunculatus $\mathrm{n}$. $\mathrm{sp}$.

Material. - 1 o (4 mm, holotype), 1 ९ (4 mm, allotype), 1 ९ (3.8 $\mathrm{mm}$, ovigerous with 2 eggs, paratype) and 6 paratypes (partially juvenile). Temisas. U.T.M.: 50118715 . Spring with running water, partially canalized, near exit of galeria (shaft for water supply). Altitude: $710 \mathrm{~m} .5$ Feb. 1989 , temp. $18^{\circ} \mathrm{C}$; cond. $450 \mu \mathrm{S} / \mathrm{cm}$; S 0.2 p.p.t. 1 specimen, same loc., Mr. D. Stock collector. 30 Mar. 1989. All material deposited in Zoölogisch Museum Amsterdam, coll. nr. Z.M.A. Amph.: 108.611.

\section{Description}

Length male $4 \mathrm{~mm}$, female $4 \mathrm{~mm}$. Colour white; blind.

Antenna 1: Somewhat shorter than half of the length of body. Flagellum 11- to 12-segmented; aesthetasc on 5th to penultimate segments, about half as long as corresponding segment (fig. 3a, c, d). Antenna 2: Peduncle scarcely spinous, flagellum 5- to 6-segmented (fig. 3b). Upper lip and lower lip as illustrated (fig. $3 \mathrm{~h}, \mathrm{j}$ ).

Mandible (fig. 3i): Palp 3-segmented; 2nd segment with 2-4 marginal setae, 3rd segment with 7 ( ) ) to 9 ( $\left(^{\circ}\right)$ D-setae, 3 E-setae, 1 A-seta and 1 Bseta. Molar rounded, 3-4 setae between molar and lacinia mobilis. Left lacinia with 4 teeth, right lacinia bilobed (each lobe finely toothed and tricuspidate). Incisor 5-dentate.

Maxilla 1 (fig. 3f): Palp with 4-7 distal setae. Outer lobe with 7 spines, ornamented from lateral to medial with following number of denticles: 3:0-2:0-3:1-2:3:1-3:1-3. Inner lobe with 2 distal setae. Maxilla 2 (fig. 3g): Outer lobe with 3-4 long laterodistal setae and 1 short seta, and 1 group of ca. 10 or more distal setae. Inner lobe: ca. 10 or more distal elements.

Maxilliped (fig. 3e): Inner lobe with 2 distal spines, 2 subdistal spines and 4 distal setae. Outer lobe with 10 or 12 spines on laterodistal margin, increasing in size towards distal border, and with 8 submarginal setae. Palp, segment 2 with 15 (less in ф) lateral setae.

Gnathopod 1 (fig. 4a): Coxal plate with 2 ventral setae. Basis with $2\left(\sigma^{\circ}\right)$ to $6(Q)$ long setae on posterior margin, 1-2 short setae on anterior margin. 


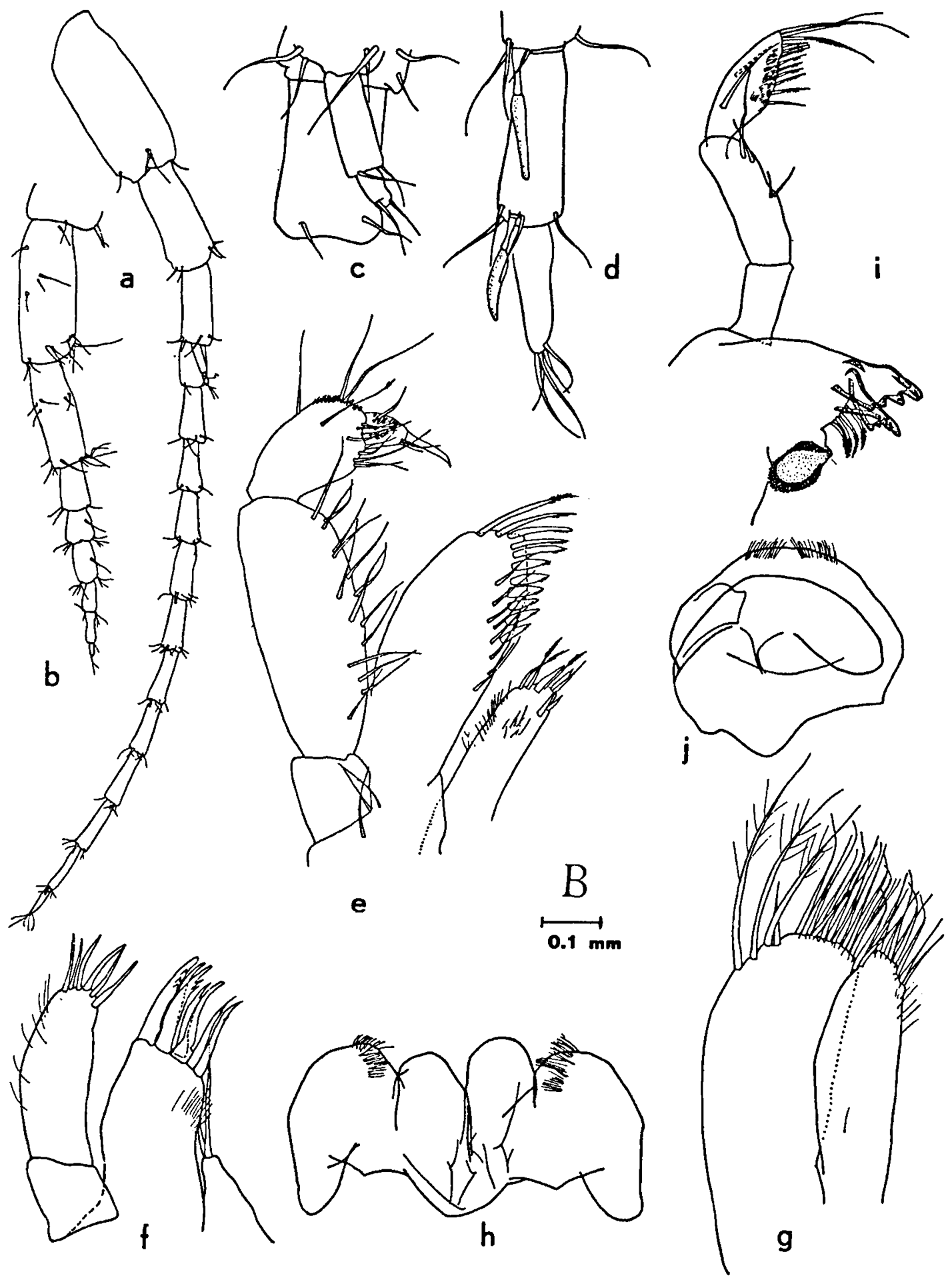

Fig. 3. $P$. pedunculatus n. sp. a: antenna $1(\sigma 4 \mathrm{~mm})$ (E); b: antenna 2 ( $\sigma 4 \mathrm{~mm}$ ) (E); c: accessory flagellum $\$ 4 \mathrm{~mm})$ (A); d: terminal segments of Al ( 4 mm) (A); e: maxilliped ( $\sigma^{\circ} 4 \mathrm{~mm}$ ) (B); f: maxilla 1 ( $\sigma^{\circ} 4 \mathrm{~mm}$ ) (A); g: maxilla 2 ( $\left.\sigma^{\circ} 4 \mathrm{~mm}\right)$ (A); h: lower lip ( $\sigma^{\circ}$ $4 \mathrm{~mm})(C)$; i: mandible ( $\left.{ }^{\circ} 4 \mathrm{~mm}\right)(\mathrm{E}) ; \mathrm{j}$ : upper lip ( $\left.\circ 4 \mathrm{~mm}\right)(C)$. 




Fig. 4. P. pedunculatus n. sp. a: gnathopod $1\left(\sigma^{\circ} 4 \mathrm{~mm}\right.$ ) (E); b: palmar angle of gnathopod 1 ( $\left({ }^{\circ} 4 \mathrm{~mm}\right)$ (D); c: gnathopod $2\left(\sigma^{\circ} 4 \mathrm{~mm}\right)$

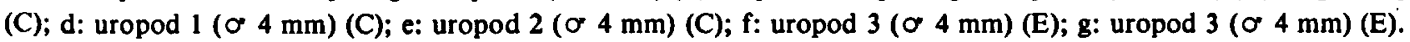


Carpus: Slighty shorter in $९$ than in $\sigma^{\circ}$, with 3 ( $\left.९\right)$ or $4\left(\sigma^{*}\right)$ groups of setae on posterior margin, 2 groups of medial setae. Propodus with 1 group of setae on posterior margin, 3-4 bifid spines on palmar angle (fig. 4b). Gnathopod 2 (fig. 4c): Coxal plate with 2-3 ventral setae. Basis with $4\left(\sigma^{*}\right)$ or 6 $(\&)$ long setae on posterior margin, 2 long $\left(\sigma^{\circ}\right)$ setae or 1 long and 1-2 short ( $($ ) setae on anterior margin. Carpus with 1 group of setae on posterior margin, 1 group of mediodistal setae and 1 long + 1-2 short anterodistal setae. Propodus with 2 (q) or $3\left(\sigma^{*}\right)$ groups of setae on posterior margin and 3 spines on palmar angle.

Pereopod 3 (fig. 5a): Coxal plate with 2-3 ventral setae. Basis with $4\left(\sigma^{\circ}\right)$ or 5-7 ( $($ ) long setae on posterior margin, 1-2 long setae and 2 short setae on anterior margin. Dactylus as long as unguis. P4 (fig. 6a): Coxal plate with 2-3 ventral setae, posterior emargination long and rather deep. Basis with $2\left(\sigma^{*}\right)$ or 5-6 ( $\left.९\right)$ long setae on posterior margin, 1 short seta on anterior margin. Dactylus as long as unguis.

P5 (fig. 5b, c): Basis with 2 ( $\left(\right.$ ) or $3\left(\sigma^{\circ}\right)$ spines on anterior margin, $5(\%)$ or $6\left(\sigma^{\circ}\right)$ posterior setules. Dactylus somewhat longer than unguis. P6 (fig. $5 \mathrm{~d}, \mathrm{e}$ ): Basis with 4 spines on anterior margin, $6\left(\sigma^{\circ}\right)$ or $7(\%)$ setules on posterior margin. Dactylus half as long as unguis. P7 (fig. 5f, g): Basis with 4-6 anterior spines, $6(\%)-8\left(\sigma^{\circ}\right)$ setules on posterior margin. Dactylus twice as long as unguis.

P5 to P7: Posterior lobe non-overhanging, without sexual dimorphism, claws slender. P5 > P6 > P7.

Coxal gills on Gn 2 to P6. On Gn 2, P5 and P6, rounded and somewhat shorter than basis; P3 and $\mathrm{P} 4$ as long as basis, stalks short. Oostegites linear; on Gn 2, P3, P4, and P5.

Epimeral plates (fig. 6b): Posterior margin more or less rounded with 3 setules, ventral margin rounded and armed as follows: 1st plate with $0-1$ spine, 2nd plate with 1-2 spines, and 3rd plate with 1-2 spines. Posteroventral corner with a welldeveloped point.

Uropods: U1 (fig. 4d) without basofacial spine, 3 spines on peduncle, $1-2$ distal spines $(1+1$ or $2+0$ ), endo- and exopodite with 1 marginal spine, sometimes unarmed in $\%$. U2 (fig. 4e) with 1 spine on peduncle, 1 distal spine, rami with terminal spines only. U3 (fig. $4 \mathrm{~g}, \mathrm{f}$ ) sexually dimorphic, in $\sigma^{*}$ with elongated peduncle and exopodite. Exopodite o 1.5 times longer than length of peduncle, upcurved, and 17 times longer than wide; peduncle 7 times longer than wide; exopodite with about 6 groups of marginal spines; peduncle armed with fewer marginal spines. In $\&$ peduncle not elongated, exopodite 7 times longer than wide, with 1-3 groups of marginal spines, length of these spines as those of endopodite.

Telson (fig. 6c, d): Subquadrate, distal margin straight in $\sigma^{\prime}$, and slightly sinuous in $९ ; 2$ ( $)$ to 3-4 $\left(\sigma^{\circ}\right)$ laterodistal spines in small lateral depressions; 2 setae near proximal margin and 2 setules in lateral position.

\section{Morphological comparison with the species of the branchiatus group}

The new species can be placed in the branchiatus group by the following characters: posterior excavation of coxa 4 of medium depth, basis of P5 to P7 with non-overhanging posterodistal lobe, epimeral plates with 1-2 spines, uropod 3 sexually dimorphic (peduncle and exopodite strongly elongated in the male). The members of the group are:

$P$. branchiatus Stock, 1980; $P$. nevadensis Notenboom, 1987a; P. granadensis Notenboom, 1987a; P. grandis Notenboom, 1987a; P. affinis Notenboom, 1987a; $P$. illustris Notenboom, 1987a; $P$. vomeratus Notenboom, 1987a; $P$. stocki Notenboom, 1987a; and $P$. adriaticus Karaman, 1955. $P$. elongatus Stock, 1980 is incertae sedis within the group. We have studied the following other species, because these also have the peduncle of U3 o' elongated: $P$. africanus Chevreux, 1901, $P$. macrotelsonis Stock, 1980, and the recently described new species $P$. mercadali Pretus, 1989.

P. mercadali Pretus, 1989: Basofacial spine on U1 present, 6 spines on outer lobe of Mx 1, characteristic spur on metasomite II, P5 to P7 with overhanging posteroventral lobe, and telson with distal notch. None of these characters are shared with the new species. Moreover the exopodite of U3 is 3 times longer than the peduncle in $P$. mercadali. 




Fig. 5. P. pedunculatus n. sp. a: pereopod $3(\% 4 \mathrm{~mm})(\mathrm{E})$; b: pereopod $5(\sigma 4 \mathrm{~mm})(\mathrm{E})$; c: basis of P5 (Q $4 \mathrm{~mm})(\mathrm{E})$; d: pereopod

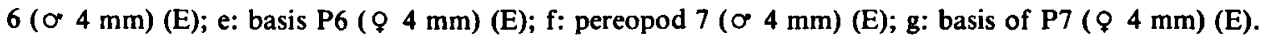




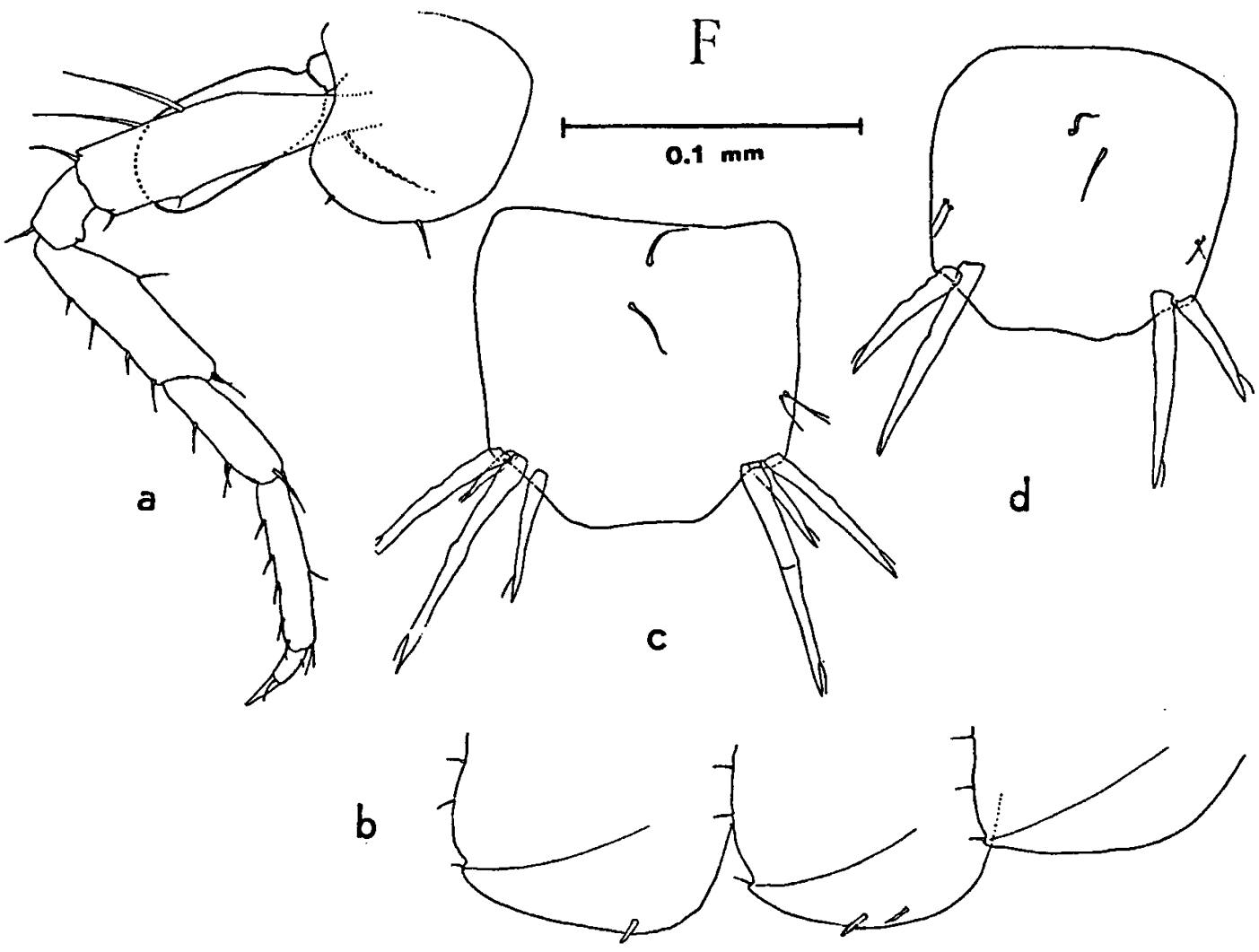

Fig. 6. P. pedunculatus n. sp. a: pereopod 4 ( $\left.\sigma^{\circ} 4 \mathrm{~mm}\right)(\mathrm{E})$; b: epimeral plates ( $\left.\$ 4 \mathrm{~mm}\right)(\mathrm{E})$; c: telson $\left(\sigma^{\circ} 4 \mathrm{~mm}\right)(\mathrm{F})$; d: telson $(Q$ $4 \mathrm{~mm})(\mathrm{F})$.

P. granadensis Notenboom, 1987a: 1-2 basofacial spines and strong spination on U1, U2 with more spines than in the new species, Gn 1 with 7 spines on palmar angle, telson in the largest specimens with apical spines, exopodite of $\mathrm{U} 3$ in $\$$ more spinous, and degree of elongation of $\mathrm{U} 3\left(O^{\circ}\right)$ different (2.5 times as long as length of peduncle in $P$. granadensis versus 1.5 times in the new species).

$P$. grandis Notenboom, 1987a: U1 as in $P$. granadensis, $\mathrm{U} 2$ with more spines on peduncle and rami, telson with distal cleft and spines along distal margin. Exopodite of U3 ( $\%$ ) 11 times longer than wide and with more spines on margin; finally exopodite of U3 $\left(\sigma^{\circ}\right)$ 2-3 times longer than peduncle.

$P$. affinis Notenboom, 1987a: U1 with basofacial spine, U2 peduncle strongly armed on dorsal and distal margin, with marginal spines on rami, telson with distal notch, exopodite of U3 ( $\%$ ) 15 times longer than wide, and exopodite of U3 $\left(O^{\circ}\right)$ twice as long as peduncle.
P. stocki Notenboom, 1987a: U1, telson, U2 and U3 of $\sigma^{\prime}$ as in P. affinis; moreover outer lobe of $\mathrm{Mx}$ 1 with 8 spines.

P. vomeratus Notenboom, 1987a: U1 with strong spinosity on peduncle (dorsally and distally) and rami, U2 with spines on rami, telson with distal notch, exopodite of U3 ( $\%$ ) as in $P$. grandis, exopodite of U3 $\left(O^{\circ}\right)$ as in $P$. mercadali.

$P$. nevadensis Notenboom, 1987a: U1, U2 as $P$. vomeratus, telson with distal notch, spines on outer lobe of Mx 1 unidenticulate, and exopodite of U3 $\left(O^{\circ}\right)$ as in $P$. mercadali.

$P$. africanus Chevreux, 1901: U1 with basofacial spine, telson with distal notch, slight sexual dimorphism in basis of P5-P7, exopodite of U3 ( 9 ) only 5 times longer than wide versus 7 times in the new species.

$P$. macrotelsonis Stock, 1980: as $P$. africanus, but in $P$. macrotelsonis without basofacial spine; shape of epimeral plates very different. 
$P$. adriaticus Karaman, 1955 is most closely related to $P$. pedunculatus, but has a well developed sexual dimorphism in the shape of the basis of P5 to $P 7$, and the habitat is marine in contradistinction to the new species $(P$. pedunculatus lives in fresh waters).

P. elongatus Stock, 1980: Basis of P5 to P7 as in adriaticus, telson with distal notch, $\mathrm{U} 1$ with basofacial spine, exopodite of U3 ( $\%$ ) 11-15 times longer than wide, and exopodite of U3 ( $\sigma^{\circ}$ ) 1.7-2 times longer than peduncle.

$P$. branchiatus Stock, 1980: U1 as in $P$. elongatus, telson with distal notch, $\mathrm{U} 2$ with more spines on peduncle and rami, exopodite of U3 ( $\%$ ) 10-14 times longer than wide, and exopodite of $U 3\left(O^{\circ}\right)$ 2-5.5 times longer than peduncle.

The new specific combination of the various morphological characters has convinced me to describe the present material as a new species of the genus Pseudoniphargus.

Etymology. - The name pedunculatus refers to the great elongation of the peduncle of $\mathrm{U} 3$ in the male.

\section{Acknowledgements}

I express my gratitude to Prof. Dr. J.H. Stock for assistance in all stages of this work and for providing me the possibility to study the juvenile of $\boldsymbol{P}$. fontinalis from Gran Canaria, to Prof. Dr. Miguel Ibañez Génis, the Director of the Departamento de Biología Animal de la Universidad de La Laguna for his interest shown in our investigations.

The fieldwork was made possible through the financial support of the Cabildo Insular de Tenerife; the laboratory work, carried out at the Instituut voor Taxonomische Zoölogie, Universiteit van Amsterdam during a course "Island Biogeography", was subventioned by the Erasmus programme of the European Economic Community, contract ICP-88-NL-0079.

\section{References*}

Araña, V. \& J.C. Carracedo, 1978. Los volcanes de las Islas Canarias. III. Gran Canaria. 151 pp. (Ed. Rueda, Madrid).

Boutin, Cl. \& N. Coineau, 1988. Pseudoniphargus maroccanus n. sp. (subterranean amphipod), the first representative of the genus in Morocco. Phylogenetic relationships and palaebiogeography. Crustaceana, Suppl. 13: 1-19.

Chevreux, E., 1901. Amphipodes des eaux souterraines de France et d'Algérie, V. Pseudoniphargus africanus nov. gen. et spec. Bull. soc. Zool. Fr., 26: 211-216.

Karaman, G.S., 1978. Revision of the genus Pseudoniphargus Chevreux 1901 (fam: Gammaridae). Bull. Mus. civ. Stor. nat. Verona, 5: 239-258.

Notenboom, J., 1986. The species of the genus Pseudoniphargus Chevreux (Amphipoda) from northern Spain. Bijdr. Dierk., 56 (1): 75-122.

Notenboom, J., 1987a. Species of the genus Pseudoniphargus Chevreux, 1901 (Amphipoda) from the Betic cordillera of southern Spain. Bijdr. Dierk., 57 (1): 87-150.

Notenboom, J., 1987b. Lusitanian species of the amphipod Pseudoniphargus Chevreux, 1901 with a key to all known Iberian species. Bijdr. Dierk., 57 (2): 191-206.

Notenboom, J., 1988. Phylogenetic relationships and biogeography of the groundwater-dwelling amphipod genus Pseudoniphargus (Crustacea), with emphasis on the Iberian species. Bijdr. Dierk., 58 (2): 159-204.

Pretus, J., 1989. A new stygobiont amphipod Pseudoniphargus mercadali n. sp., from the island of Minorca (Balearic archipelago). Stygologia, 4 (2): 228-241.

Sánchez, E., In press. A new species of Pseudoniphargus (Crustacea, Amphipoda) from subterranean waters in Tenerife (Canary Islands). Hydrobiologia.

Stock, J.H., 1980. Regression model evolution as exemplified by the genus Pseudoniphargus (Amphipoda). Bijdr. Dierk., 50 (1): $105-144$.

Stock, J.H., 1988. The amphipod genus Pseudoniphargus (Crustacea) in the Canary Islands. Bijdr. Dierk., 58 (1): 47-78.

Stock, J.H., J.R. Holsinger, B. Sket \& Th.M. Iliffe, 1986. Two new species of Pseudoniphargus (Amphipoda), in Bermudian groundwaters. Zoologica Scr., 15 (3): 237-249.

Received: 9 June 1989

*) An extensive bibliography can be found in Stock, 1980. 